\title{
Chemical polishing of InAs, InSb, GaAs and GaSb
}

\author{
I.V.Levchenko, V.M.Tomashyk, I.B.Stratiychuk, \\ G.P.Malanych, A.S.Stanetska, A.A.Korchovyi
V.Lashkaryov Institute of Semiconductor Physics, National Academy of Sciences of Ukraine, 41 Nauki Ave., 03028 Kyiv, Ukraine

\section{Received April 11, 2017}

\begin{abstract}
The mechanism and kinetics of chemical dissolution of InAs, InSb, GaAs and GaSb in $\left(\mathrm{NH}_{4}\right)_{2} \mathrm{Cr}_{2} \mathrm{O}_{7}-\mathrm{HBr}-\mathrm{C}_{4} \mathrm{H}_{6} \mathrm{O}_{6}$ etching mixtures have been studied. Influence of tartaric acid on the parameters of chemical-dynamic polishing and morphology of the obtained crystals surface has been determined. Using of $\left(\mathrm{NH}_{4}\right)_{2} \mathrm{Cr}_{2} \mathrm{O}_{7}-\mathrm{HBr}-\mathrm{C}_{4} \mathrm{H}_{6} \mathrm{O}_{6}$ etching solutions provides the controlled removal of thin layers and the polishing of investigated semiconductors. The polishing etchant compositions have been proposed and conditions for the chemical-dynamic polishing of the InAs, InSb, GaAs and GaSb crystals have been optimized.
\end{abstract}

Keywords: semiconductor, tartaric acid, chemical-dynamic polishing, etchant, etching rate.

Исследованы механизм и кинетика процесса химического растворения $\ln A s, \ln S b$, $\mathrm{GaAs}$ и GaSb в травильных смесях $\left(\mathrm{NH}_{4}\right)_{2} \mathrm{Cr}_{2} \mathrm{O}_{7}-\mathrm{HBr}-\mathrm{C}_{4} \mathrm{H}_{6} \mathrm{O}_{6}$. Показано влияние винной кислоты на параметры химико-динамического полирования и морфологию полученной поверхности кристаллов. Использование травильных растворов на основе $\left(\mathrm{NH}_{4}\right)_{2} \mathrm{Cr}_{2} \mathrm{O}_{7}-$ $\mathrm{HBr}-\mathrm{C}_{4} \mathrm{H}_{6} \mathrm{O}_{6}$ способствует контролированному снятию тонких приповерхностных слоев и качественному финишному полированию. Предложены и оптимизированы составы полирующих растворов и условия химико-динамического полирования кристаллов InAs, InSb, GaAs и GaSb.

Хімічне полірування InAs, InSb, GaAs та GaSb. I.В.Левченко, В.М.Толашик, І.Б.Стратійчук, Г.П.Маланич, А.С.Станецька, А.А.Корчовий.

Досліджено механізм та кінетику процесу хімічного розчинення $\ln A s, \operatorname{lnSb}$, GaAs та GaSb у травильних сумішах $\left(\mathrm{NH}_{4}\right)_{2} \mathrm{Cr}_{2} \mathrm{O}_{7}-\mathrm{HBr}-\mathrm{C}_{4} \mathrm{H}_{6} \mathrm{O}_{6}$. Показано вплив винної кислоти на параметри хіміко-динамічного полірування та морфологію отриманої поверхні кристалів. Застосування травильних розчинів на основі $\left(\mathrm{NH}_{4}\right)_{2} \mathrm{Cr}_{2} \mathrm{O}_{7}-\mathrm{HBr}-\mathrm{C}_{4} \mathrm{H}_{6} \mathrm{O}_{6}$. забезпечує контрольоване зняття тонких приповерхневих шарів та якісне фінішне полірування. Запропоновано та оптимізовано склади поліруючих розчинів і умови хіміко-динамічного полірування кристалів $\ln \mathrm{As}, \ln \mathrm{Sb}$, GaAs та GaSb.

\section{Introduction}

Obtaining of polished surface is an important stage in semiconductor devices manufacturing. Often this stage is carried out by way of trials and errors, but for a wide materials spectrum it is needed the individual polishing methods. Polishing quality and purity of the substrates surface have a crucial importance for the semicon- ductor devices performance. Etching compositions should provide the surface flatness and complete removal of defective layers. Chemical polishing is one of the most common and effective methods of obtaining the smooth, stoichiometric and atomically clean semiconductors surface [1].

Nowadays there are many etching compositions for treatment of III-V semiconductors structural-defect surface layers $[2,3]$. 
Bromine containing etching compositions are widely used. The final polishing with $\mathrm{Br}_{2}-\mathrm{CH}_{3} \mathrm{OH}$ etching solutions provides obtaining the perfect mirror-like GaAs crystals surface [4].

The ternary etching compositions which contain an organic reagent are considered as more effective. The authors [5] allow that $\alpha$-hydroxy acids (lactic, citric, malic and tartaric) connect the atoms of group III A elements. This may contribute to a more uniform etching which is connected with their chelating ability to the metal ions due to presence of numerous lone electron pairs on the oxygen atoms of $-\mathrm{COOH}$ and $-\mathrm{OH}$ groups. $\alpha$-Hydroxy acids can be used not only as complexing agents, but they could also catalyze reaction to convert the etch products in soluble forms. The authors consider that lactic and tartaric acids are the best complexing agents.

Results of the chemical etching of polar planes (111)In and (11T)Sb of InSb wafers in $\mathrm{HF}: \mathrm{H}_{2} \mathrm{O}_{2}: \mathrm{C}_{4} \mathrm{H}_{6} \mathrm{O}_{6} \quad(27 \%)=1: 14: 20$ etching solutions have been presented in [6]. For (III)Sb stationary etching the dark oxide layer is formed on the wafers surface which removed easily by stirring the solution. It is due to diffusion-controlled etching process of (III)Sb plane in tartaric acid solution with a high viscosity as well as with slow removal of oxidation products. The polishing of (111)In plane was followed by formation of the round etching pits. The authors explained their formation with the crystallographic orientations areas that have dislocations and with an excess of energy around the dislocation which results in rapid etching.

The tartaric acid influence of in $\mathrm{HO}_{2}: \mathrm{HCl}: \mathrm{C}_{4} \mathrm{H}_{6} \mathrm{O}_{6}$ solutions on InAs and $\mathrm{GaAs}$ crystals etching process have been described in [7]. The removing process of In and $\mathrm{Ga}$ atoms increases due to chelation effect of $\alpha$-hydroxy acids at the organic component introduction. The chelation acid properties make possible the soluble complexes formation of III A group elements. Moreover, the authors noted that $\mathrm{C}_{4} \mathrm{H}_{6} \mathrm{O}_{6}$ breaks In-O bond slower in comparison with $\mathrm{Ga}-\mathrm{O}$ bond.

This work is devoted to research of InAs, InSb, GaAs and GaSb chemical-dynamic polishing particularities in $\left(\mathrm{NH}_{4}\right)_{2} \mathrm{Cr}_{2} \mathrm{O}_{7}-\mathrm{HBr}-$ $\mathrm{C}_{4} \mathrm{H}_{6} \mathrm{O}_{6}$ etching solutions to establish the wafers etching rate dependences on the etchant compositions, to define the compositions of the polishing solutions, to study the kinetics of the crystals dissolution proc- ess and to reveal the tartaric acid influence on the chemical etching parameters.

The interaction between $\left(\mathrm{NH}_{4}\right)_{2} \mathrm{Cr}_{2} \mathrm{O}_{7}-$ $\mathrm{HBr}-\mathrm{C}_{4} \mathrm{H}_{6} \mathrm{O}_{6}$ etchants and InAs, InSb, GaAs, $\mathrm{GaSb}$ semiconductors are described for the first time in this work.

\section{Experimental}

InAs, InSb, GaAs, GaSb n-type crystals were used as investigation objects. Wafers with $5 \times 5 \times 2 \mathrm{~mm}^{3}$ size were cut using string cutting from the single-crystalline ingots. Then, they were glued on quartz substrates and were degreased using organic solvent. Experimental researches included mechanical grinding, chemical-mechanical polishing and chemical-dynamical polishing (CDP) of the crystals. The mechanical grinding was carried out using aqueous suspensions of some abrasive powders (ACM 10/7, ACM $5 / 3$ and ACM 1/0) in order of the grain abrasive diameter decreasing from 10 to $1 \mu \mathrm{m}$. Mechanical impurities were removed from the samples after every step of the grinding. They were washed according to the following scheme:

$$
\begin{gathered}
\text { surfactants solution }(1 \mathrm{~min}) \rightarrow \\
\rightarrow \mathrm{H}_{2} \mathrm{O}(\text { dist })(1 \mathrm{~min}) \rightarrow \mathrm{H}_{2} \mathrm{O}(\text { dist })(1 \mathrm{~min}) \rightarrow \\
\rightarrow \mathrm{H}_{2} \mathrm{O}(\text { dist })(1 \mathrm{~min}) .
\end{gathered}
$$

As the mechanical grinding decreases the thickness of damaged layer, the surface still remains structurally imperfect. That is why the next treatment operation was the chemical-mechanical polishing. The removing of the superficial structurally-defect layers was performed on a special etching polisher, using universal bromine emerging etchant that was developed in our laboratory [8].

The chemical-dynamic polishing process was carried out in order to investigate the nature of $\left(\mathrm{NH}_{4}\right)_{2} \mathrm{Cr}_{2} \mathrm{O}_{7}-\mathrm{HBr}-\mathrm{C}_{4} \mathrm{H}_{6} \mathrm{O}_{6}$ etchant composition influence on dissolution of InAs, InSb, GaAs and GaSb crystals superficial layers.

The semiconductors etching rate depends on the stage of interaction between the etchant components and the crystals. It depends also on the stage of dissolution of the forming oxidation products which helps to exclude the surface passivation effect. Organic reagent is an important etching compositions component which as a rule is a good complexing agent. Tartaric acid regulates the process of chemical interaction between $\left(\mathrm{NH}_{4}\right)_{2} \mathrm{Cr}_{2} \mathrm{O}_{7}$ and $\mathrm{HBr}$ and holds free $\mathrm{Br}_{2}$ in solution during the reaction. As a 
modifier of etchant viscosity $\mathrm{C}_{4} \mathrm{H}_{6} \mathrm{O}_{6}$ can decrease overall etching rate and to improve the polishing properties of the etching compositions.

Interactions between the etchant components and the semiconductors can be presented like this: $\mathrm{Br}_{2}$ breaks the InAs, InSb, GaAs and GaSb covalent bonds and then Sb and As shall be oxidized. Tartaric acid anions connect with $\mathrm{Ga}^{3+}$ and $\mathrm{In}^{3+}$ ions. Moreover, $\mathrm{C}_{4} \mathrm{H}_{6} \mathrm{O}_{6}$ promotes to the etching IIIand V-group component removing simultaneously. Smooth polishing surface is formed as a result of these properties. The $\left(\mathrm{C}_{4} \mathrm{H}_{4} \mathrm{O}_{6}{ }^{2-}\right)$ tartrates as chelating reaction products are good soluble in water and could be removed together with reacted mixture components when the etched surface let down into water.

The experimental researches range was determined using method of mathematical planning on the simplex [9]. Using such method we avoid the large number of unpolishing solution areas.

The mechanism and kinetics of the crystals dissolution were studied on the device for CDP using the method of disk rotating [10]. The CDP experiments were performed in the reproducible hydrodynamic conditions at $T=294-298 \mathrm{~K}$ and disc speed rotation of $\gamma=78 \mathrm{rpm}$ for 5-10 min. Aqueous solutions of 26 wt. $\%\left(\mathrm{NH}_{4}\right)_{2} \mathrm{Cr}_{2} \mathrm{O}_{7}$ (reagent grade), 42 wt. \% $\mathrm{HBr}$ (extrapure grade) and 27 wt. $\% \quad \mathrm{C}_{4} \mathrm{H}_{6} \mathrm{O}_{6}$ (tartaric acid, reagent grade) were used as initial reagents. Further they are called as s. $\left(\mathrm{NH}_{4}\right)_{2} \mathrm{Cr}_{2} \mathrm{O}_{7}$, s. $\mathrm{HBr}$, and s. $\mathrm{C}_{4} \mathrm{H}_{6} \mathrm{O}_{6}$.

The solutions were left for $2 \mathrm{~h}$ to complete the reaction between the mixture components. The elementary bromine released as a result of the etchant components interaction. The chemical equilibrium was reached in the solution when $\mathrm{Br}_{2}$ formation process was stopped.

Washing process of the crystals was carried out after every CDP operations. The etching rate changes were defined comparing the difference of the wafers thickness before and after CDP. The thickness measurements were carried out using electronic indicator TESA DIGICO 400 with accuracy of $0.02 \mu \mathrm{m}$.

Surface morphology after the etching was investigated in white light by metallographic analysis using MIM-7 microscope with a eTREK DCM800 digital camera with increase from $25 \times$ to $1600 \times$.

Geometric parameters of the semiconductor polished surfaces were studied by scan-

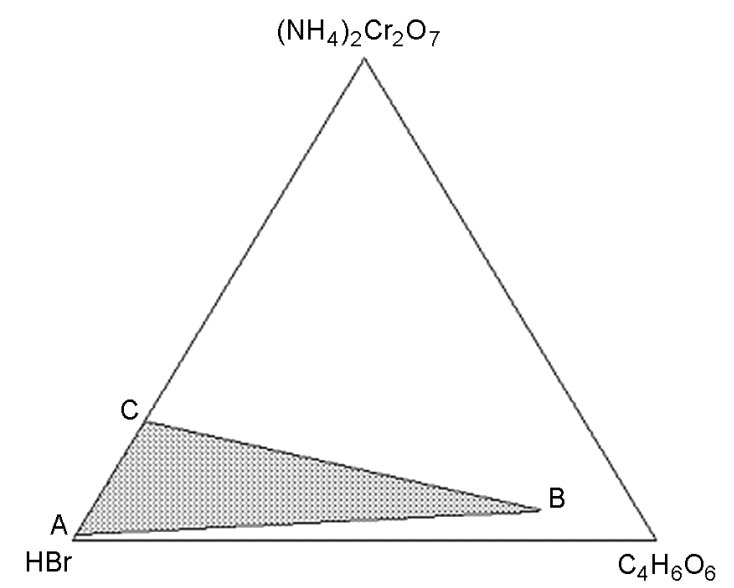

Fig. 1. Range of investigated etching solutions interval (in vol. \%): (222) $\left(\mathrm{NH}_{4}\right)_{2} \mathrm{Cr}_{2} \mathrm{O}_{7}:(10-98) \mathrm{HBr}:(0-80) \mathrm{C}_{4} \mathrm{H}_{6} \mathrm{O}_{6}$.

ning probe microscope NanoScope III a Dimension 3000 TM (Digital Instruments, USA) using atomic force microscopy (AFM) in periodic contact mode (tapping mode) on air.

\section{Results and discussion}

For investigation, the concentration interval with the ratio of initial components concentrations (in vol.\%): $(2-22) \mathrm{s}$. $\left(\mathrm{NH}_{4}\right)_{2} \mathrm{Cr}_{2} \mathrm{O}_{7}:(10-98) \mathrm{HBr}:(0-80) \mathrm{C}_{4} \mathrm{H}_{6} \mathrm{O}_{6}$ was chosen (Fig. 1). Aqueous solutions of $26 \mathrm{wt}$. $\%\left(\mathrm{NH}_{4}\right)_{2} \mathrm{Cr}_{2} \mathrm{O}_{7}, 42$ wt. \% $\mathrm{HBr}, 27$ wt. \% $\mathrm{C}_{4} \mathrm{H}_{6} \mathrm{O}_{6}$ are presented as the diagram components. The "etchant compositions - etching rate" diagrams were constructed and the etching rates concentration dependences on the etchant compositions were defined as the results of the experimental researches (Fig. 2).

The polishing solutions were defined in the interval (in vol. \%); $(2-22)$ s. $\left(\mathrm{NH}_{4}\right)_{2} \mathrm{Cr}_{2} \mathrm{O}_{7}$ in $\mathrm{s}$. $\mathrm{HBr}$ when InAs, InSb, GaAs and $\mathrm{GaSb}$ semiconductors dissolved in $\left(\mathrm{NH}_{4}\right)_{2} \mathrm{Cr}_{2} \mathrm{O}_{7}-$ $\mathrm{HBr}$ etching mixtures. The etching rate changed from $0.9 \mu \mathrm{m} / \mathrm{min}$ to $8.4 \mu \mathrm{m} / \mathrm{min}$ in this concentration interval.

The interaction between semiconductor and $\left(\mathrm{NH}_{4}\right)_{2} \mathrm{Cr}_{2} \mathrm{O}_{7}-\mathrm{HBr}-\mathrm{C}_{4} \mathrm{H}_{6} \mathrm{O}_{6}$ solutions is characterized by the next regularities. The etching rates of all crystals decrease to minimum value $(0.1 \mu \mathrm{m} / \mathrm{min})$ when $\mathrm{s} . \mathrm{C}_{4} \mathrm{H}_{6} \mathrm{O}_{6}$ concentration reaches the maximum value. With increase of $\mathrm{s}$. $\left(\mathrm{NH}_{4}\right)_{2} \mathrm{Cr}_{2} \mathrm{O}_{7}$ concentration the etching rate increases to maximum (5.6-7.5 $\mu \mathrm{m} / \mathrm{min}$ for InAs and GaAs and $7.9-8.4 \mu \mathrm{m} / \mathrm{min}$ — in the case of InSb and $\mathrm{GaSb})$. Isolines of the same dissolution rates of InAs and GaAs are similar. The 


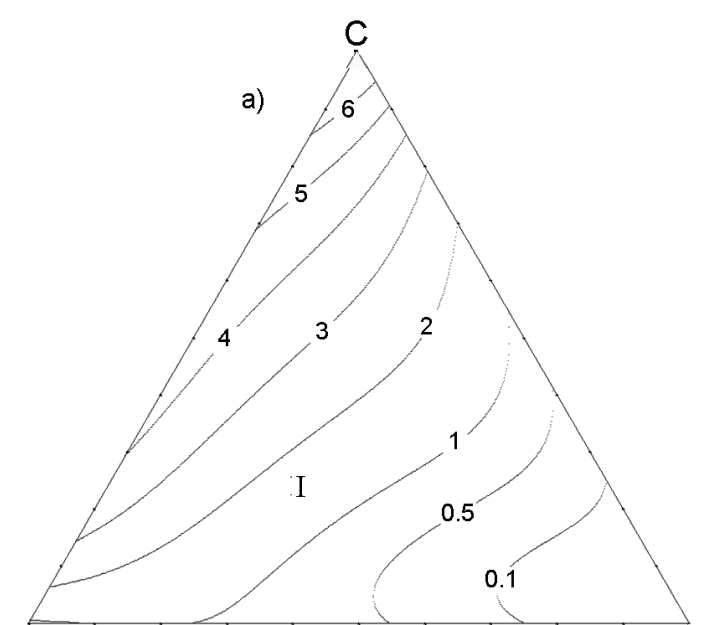

A

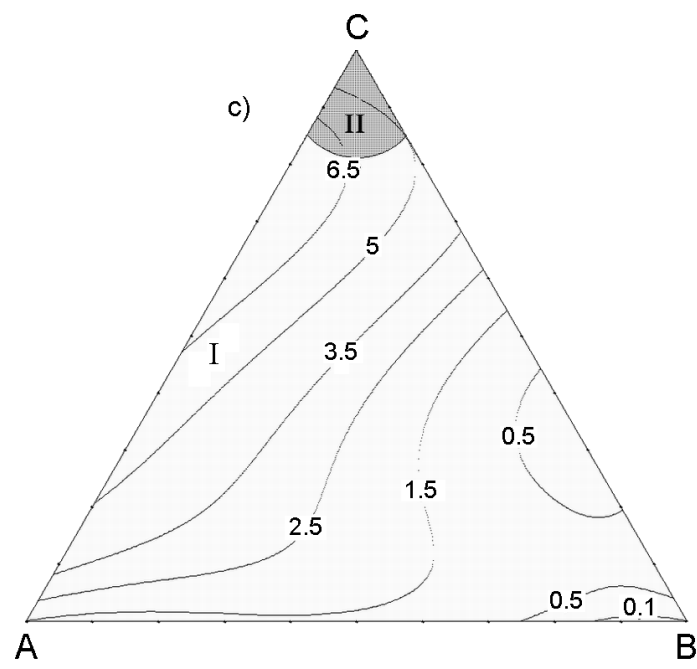

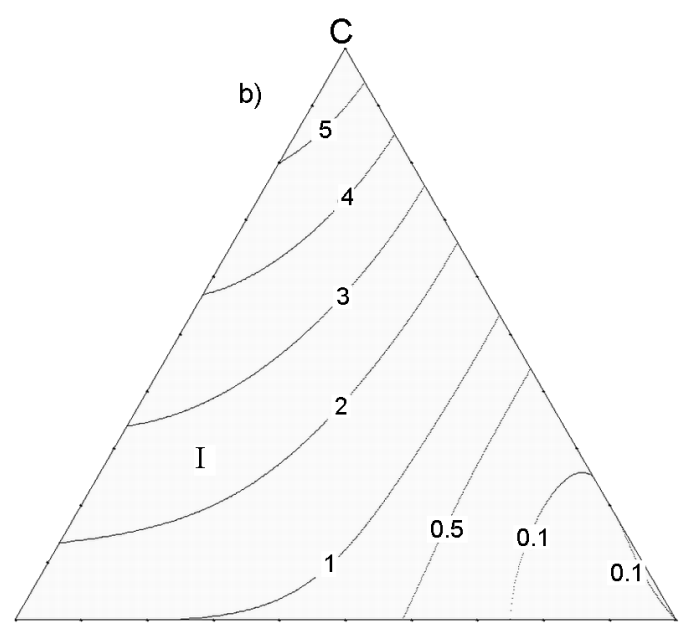

$A$

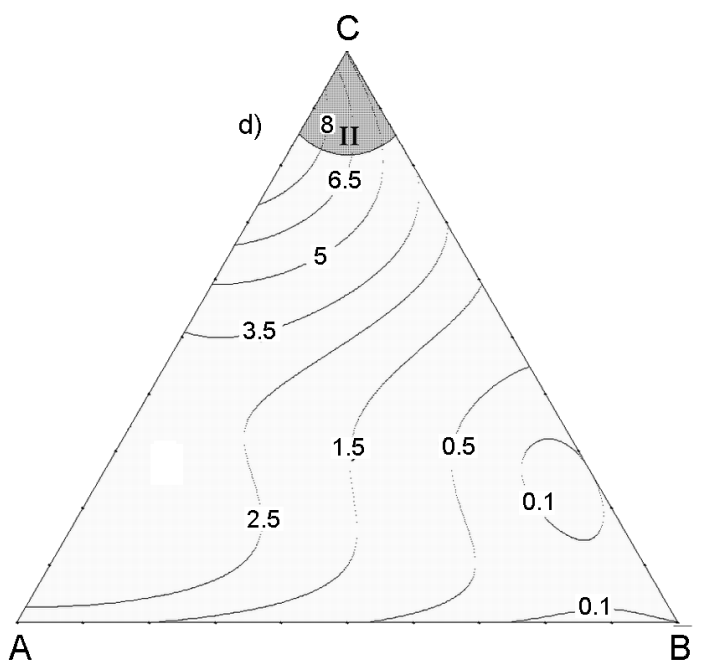

Fig. 2. Concentration dependences of (a) InAs, (b) InSb, (c) GaAs, and (d) GaSb etching rate $(\mu \mathrm{m} / \mathrm{min})$. $\left(\mathrm{NH}_{4}\right)_{2} \mathrm{Cr}_{2} \mathrm{O}_{7}-\mathrm{HBr}-\mathrm{C}_{4} \mathrm{H}_{6} \mathrm{O}_{6}$ volume ratio in corners $\mathrm{A}, \mathrm{B}, \mathrm{C}$ is $(2: 98: 0)$; (10:10:80); (22:78:0); I - polishing region, II - unpolishing region $(T=292-294 \mathrm{~K}, \gamma=78 \mathrm{rpm})$.

same situation is observed for $\operatorname{lnSb}$ and GaSb crystals. The maximum value of the InAs and GaAs dissolution rate is achieved at 22 vol. $\%$ s. $\left(\mathrm{NH}_{4}\right)_{2} \mathrm{Cr}_{2} \mathrm{O}_{7}$ in the etching composition. In the case of InSb and GaSb the maximum value of the etching rate is achieved at 17 vol. $\%$ s. $\left(\mathrm{NH}_{4}\right)_{2} \mathrm{Cr}_{2} \mathrm{O}_{7}$ in the mixture. Such tendency can be explained by the film formation on the antimonide surface, which limits interaction between the crystals and active components of the etching solution. Such different behavior of semiconductors treatment can be also due to the difference in the physical and chemical crystals properties.

Therefore we can argue about the similarity between the semiconductors dissolution mechanisms of InAs and GaAs, as well as InSb and GaSb. The tartaric acid presence in $\left(\mathrm{NH}_{4}\right)_{2} \mathrm{Cr}_{2} \mathrm{O}_{7}-\mathrm{HBr}-\mathrm{C}_{4} \mathrm{H}_{6} \mathrm{O}_{6}$ etching composition leads to the overall etching rate decrease. It is due to chelation effect of tartaric acid and changing of the etching solution viscosity. The viscosity increase slows the reagent interaction process and it promotes the overall etching rate decrease.

The concentration intervals of the polishing and unpolishing solutions were defined by assessing of substrates surface which obtained after CDP. In the case of InAs and GaAs, the mirror-like polishing surface was formed in all etching compositions. But in the etching solutions (in vol. \% ): $\quad 19\left(\mathrm{NH}_{4}\right)_{2} \mathrm{Cr}_{2} \mathrm{O}_{7}-61 \mathrm{HBr}-20 \mathrm{C}_{4} \mathrm{H}_{6} \mathrm{O}_{6}$ and $14\left(\mathrm{NH}_{4}\right)_{2} \mathrm{Cr}_{2} \mathrm{O}_{7}-66 \mathrm{HBr}-20 \mathrm{C}_{4} \mathrm{H}_{6} \mathrm{O}_{6}$ the round etching pits were formed on the InAs surface. The reason of their formation is explained in [6]. The polishing solutions boundaries (regions I) of the InAs, GaAs crystals are limited by the interval 


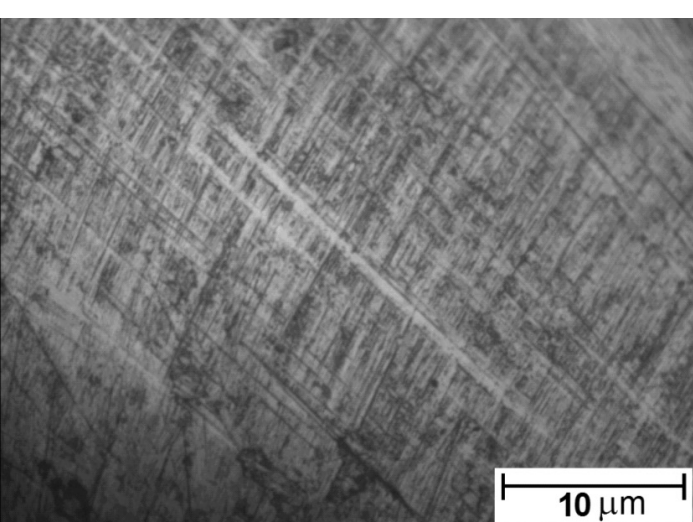

a)

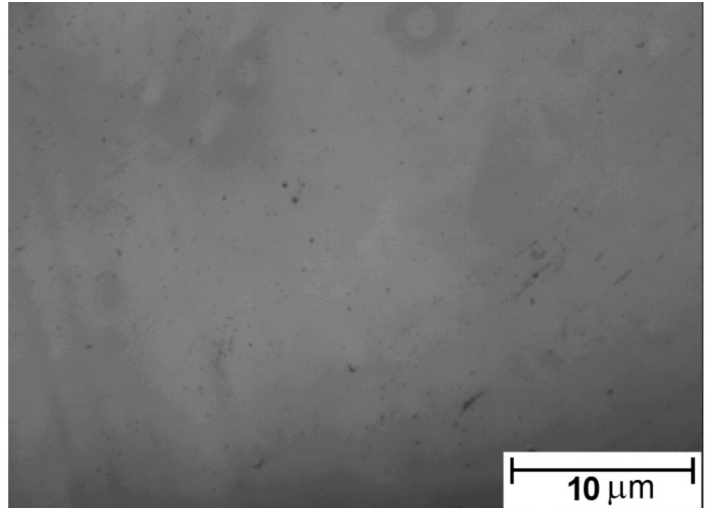

b)

Fig. 3. InSb surface microstructure after: (a) grinding with ASM 1/0, (b) CDP in etching composition (in. vol. \% ): $8\left(\mathrm{NH}_{4}\right)_{2} \mathrm{Cr}_{2} \mathrm{O}_{7}-32 \mathrm{HBr}-60 \mathrm{C}_{4} \mathrm{H}_{6} \mathrm{O}_{6}$.

(in vol. \%): (2-19) $\left(\mathrm{NH}_{4}\right)_{2} \mathrm{Cr}_{2} \mathrm{O}_{7}:(10-98)$ $\mathrm{HBr}:(0-80) \mathrm{C}_{4} \mathrm{H}_{6} \mathrm{O}_{6}$.

Two types of surface morphology were observed in the case of InSb and GaSb. The surface was smooth and polished in the concentration interval (vol.\%): (2-19) $\left(\mathrm{NH}_{4}\right)_{2} \mathrm{Cr}_{2} \mathrm{O}_{7}:(10-98) \mathrm{HBr}: \quad(0-80)$ tartaric acid. This interval formed the polishing solutions regions. When $\left(\mathrm{NH}_{4}\right)_{2} \mathrm{Cr}_{2} \mathrm{O}_{7}$ concentration is the maximum in the etching composition, a white film was formed on the InSb and GaSb surface. This can be due to the formation of the $\mathrm{Sb}_{2} \mathrm{O}_{3}$ or $\mathrm{Sb}_{2} \mathrm{O}_{5}$ insoluble oxides. The boundaries of unpolishing solutions (region II) for the antimonides are limited by the following compositions (in vol. \% ): (19-22) $\quad\left(\mathrm{NH}_{4}\right)_{2} \mathrm{Cr}_{2} \mathrm{O}_{7}: \quad$ (6981) $\mathrm{HBr}:(0-11) \mathrm{C}_{4} \mathrm{H}_{6} \mathrm{O}_{6}$.

Absence of the unpolishing regions for InAs and GaAs can be explained by the fact that $A s$ is removed from the surface as $\mathrm{As}(\mathrm{OH})_{3}$ or $\left(\mathrm{AsO}_{4}\right)^{3-}$. $\mathrm{As}_{2} \mathrm{O}_{3}$ is formed when the arsenides are oxidized. It is easily dissolved in water:

$$
\mathrm{As}_{2} \mathrm{O}_{3}+3 \mathrm{H}_{2} \mathrm{O}=2 \mathrm{As}(\mathrm{OH})_{3} \text {. }
$$

The following reactions are possible in the acidic solutions:

$$
\begin{aligned}
& \mathrm{As}_{2} \mathrm{O}_{3}+4 \mathrm{H}^{+}+\mathrm{H}_{2} \mathrm{O}=2 \mathrm{H}_{3} \mathrm{AsO}_{4}, \\
& \mathrm{As}(\mathrm{OH})_{3}+\mathrm{H}^{+}=\mathrm{As}(\mathrm{OH})_{2}^{+}+\mathrm{H}_{2} \mathrm{O} .
\end{aligned}
$$

As for $\mathrm{Sb}_{2} \mathrm{O}_{3}$, this oxide can be avoid by adding a fresh portion of the etchant. Tartaric acid reacting with the oxide forms a soluble complex

$$
\begin{gathered}
\mathrm{Sb}_{2} \mathrm{O}_{3}+2 \mathrm{C}_{4} \mathrm{H}_{6} \mathrm{O}_{6} \rightarrow \\
\rightarrow 2\left[\mathrm{Sb}\left(\mathrm{C}_{4} \mathrm{H}_{2} \mathrm{O}_{6}\right)\left(\mathrm{H}_{2} \mathrm{O}\right)\right]^{-}+\mathrm{H}_{2} \mathrm{O}+2 \mathrm{H}^{+} .
\end{gathered}
$$

The data of metallographic analysis of the InAs surface after grinding and chemical-dynamic polishing are presented in Fig. 3. Such changes of the surface morphology were the same for all crystals. It shows that the $\left(\mathrm{NH}_{4}\right)_{2} \mathrm{Cr}_{2} \mathrm{O}_{7}-\mathrm{HBr}-\mathrm{C}_{4} \mathrm{H}_{6} \mathrm{O}_{6}$ etching solutions promote to form the smooth surface morphology and to remove the thin surface layers uniformly over the entire surface.

According to the AFM researches, the InAs and InSb surface roughness after CDP in the polishing solution have $R_{a}=3.3 \mathrm{~nm}$ (for InAs) and $R_{a}=2.8 \mathrm{~nm}$ (for InSb). After chemical treatment the semiconductors have the super smooth surface, because $R_{a}$ data are less than $10 \mathrm{~nm}$ [11].

Kinetics of the semiconductors dissolution was defined by investigating the etching rate dependences on the solution mixing (Fig. 4a) and temperature (Fig. 4b). The graphic dependences make it possible to determine the limiting stage of the crystals dissolution process. The dependences (Fig. $4 \mathrm{a})$ were build using equation of $v^{-1}=$ $1 / k C_{0}+\left(a / D C_{0}\right) \gamma^{-1 / 2}$. Such dependences tend to the origin when the first member of the equation $\left(1 / k C_{0}\right)$ is zero. It indicates the diffusion-limited nature of the crystal dissolution. The angle of the slope line decreases when influence of the chemical reaction on the interaction rate is increasing. The chemical reaction limits the etching process when the second member of the equation $\left(\left(a / D C_{0}\right) \gamma^{-1 / 2}\right)$ is zero. In such a case, the line is parallel to the abscissa axis. The dependences line cuts off the ordinate axis when the semiconductors dissolution process has mixed (diffusion-kinetic) mechanism [10]. 

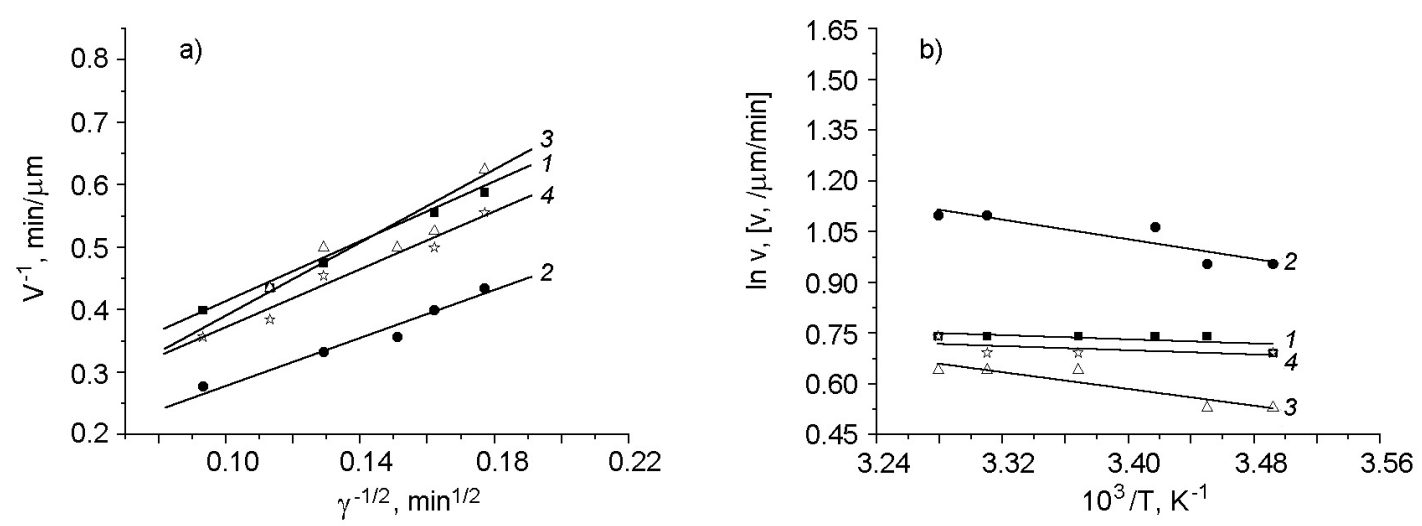

Fig. 4. Etching rate dependences of (1) InAs, (2) InSb, (3) GaAs, and (4) GaSb crystals on (a) disk rotation speed $(I=293 \mathrm{~K})$ and $(\mathrm{b})$ solution temperature $(\gamma=78 \mathrm{rpm})$ in the etching mixture (in vol. \%): $9\left(\mathrm{NH}_{4}\right)_{2} \mathrm{Cr}_{2} \mathrm{O}_{7}-71 \mathrm{HBr}-20 \mathrm{C}_{4} \mathrm{H}_{6} \mathrm{O}_{6}$.

The investigations were carried out in the etching solution with 9 vol. $\%$ s. $\left(\mathrm{NH}_{4}\right)_{2} \mathrm{Cr}_{2} \mathrm{O}_{7}$. The etching rate increases for all crystals treatment when disk rotation speed is increased in 32-116 rpm interval of the disk rotation. This confirms that hydrodynamic conditions of polishing solution promote the fresh etchant inflow and help to support the reagents interaction. The obtained dependences cut off a segment on the vertical axis, indicating a the mixed (diffusion-kinetic) mechanism of dissolution process.

The dissolution rate dependences versus temperature were also analyzed (Fig. 4b). It was found that the solution temperature increasing has almost no effect on the reaction rate. The values of apparent activation energy $\left(E_{q}\right)$ are less than $35 \mathrm{~kJ} / \mathrm{mol}$. This confirms that crystals dissolution process is limited by the diffusion stage. Indeed, the diffusion control of the chemical interaction process is realized at the low values of energy activation $\left(E_{a} \leq 35 \mathrm{~kJ} / \mathrm{mol}\right)$. The difference of dissolution process determination was due to the fact that the diffusion stage dominates in the mixed mechanism.

\section{Conclusions}

The "etchant composition - etching rate" dependences were constructed using the data of InAs, InSb, GaAs and GaSb chemical-dynamic polishing in the reproducible hydrodynamic conditions. It is found that the etching rates increase from $0.15 \mu \mathrm{m} / \mathrm{min}$ to $5.6-7.5 \mu \mathrm{m} / \mathrm{min}$ for InAs and GaAs and to 7.9-804 $\mu \mathrm{m} / \mathrm{min}$ in the case of InSb and GaSb when s. $\left(\mathrm{NH}_{4}\right)_{2} \mathrm{Cr}_{2} \mathrm{O}_{7}$ concentration increases. Boundaries of the polishing solutions (region I) (in vol.\% ): $(2-22)\left(\mathrm{NH}_{4}\right)_{2} \mathrm{Cr}_{2} \mathrm{O}_{7},(10-98) \mathrm{HBr}$ and
(0-80) tartaric acid for InAs and GaAs and in the case of InSb and GaSb (in vol. \%): (2-19) $\left(\mathrm{NH}_{4}\right)_{2} \mathrm{Cr}_{2} \mathrm{O}_{7},(10-98) \mathrm{HBr}$ and $(0-80)$ $\mathrm{C}_{4} \mathrm{H}_{6} \mathrm{O}_{6}$ were defined. The unpolishing solutions interval (region II) is characterized only for antimonides and contain (in vol. \% ): (19-22) $\left(\mathrm{NH}_{4}\right)_{2} \mathrm{Cr}_{2} \mathrm{O}_{7}:(69-81) \mathrm{HBr}:(0-$ 11) $\mathrm{C}_{4} \mathrm{H}_{6} \mathrm{O}_{6}$. It is established that the kinetics of the crystals dissolution has the diffusion nature. The crystal etching rate decreases when s. $\mathrm{C}_{4} \mathrm{H}_{6} \mathrm{O}_{6}$ concentration increases in the etching composition. It is found that the investigated etching system has the etching solutions regions which can be used for the highquality final polishing of the InAs, InSb, GaAs and GaSb crystals surface.

\section{References}

1. B.Tuck, J.Mater.Sci., 10, 321 (1975).

2. D.Allwood, N.Mason, A.Mowbray et al., $J$. Cryst. Growth, 248, 108 (2003).

3. J.S.Song, Y.C.Choi, S.H.Seo et al., J.Cryst. Growth, 264, 98 (2004).

4. K.Bock, A.Grtib, H.L.Hartnage, J.Electrochem.Soc., 137, 3301 (1990).

5. P.Bandaruz, E.Yablonovitch, J.Electrochem. Soc., 149, G599 (2002).

6. S.O.Eminov, K.D.Jalilova, E.A.Mamedova, Inorg. Mater., 47, 340 (2011).

7. P.Mancheno-Posso, A.J.Muscat, Solid State Phenomena, 219, 52 (2015).

8. Z.F.Tomashyk, Ye.O.Bilevych, V.M.Tomashyk, Condens. Matter and Interphases, 1, 327 (2001).

9. F.S.Novik, Simplex Simulation of the Experiment in the Metallurgical Systems Investigation, Metallurgiya, Moscow (1985) [in Russian].

10. V.A.Perevoshchikov, Vysokochistye Veshchestva, 2, 5 (1995).

11. S.S.Pop, I.S.Sharodi, Physical Electronics, Yevrosvit, Lviv (2001) [in Ukrainian]. 